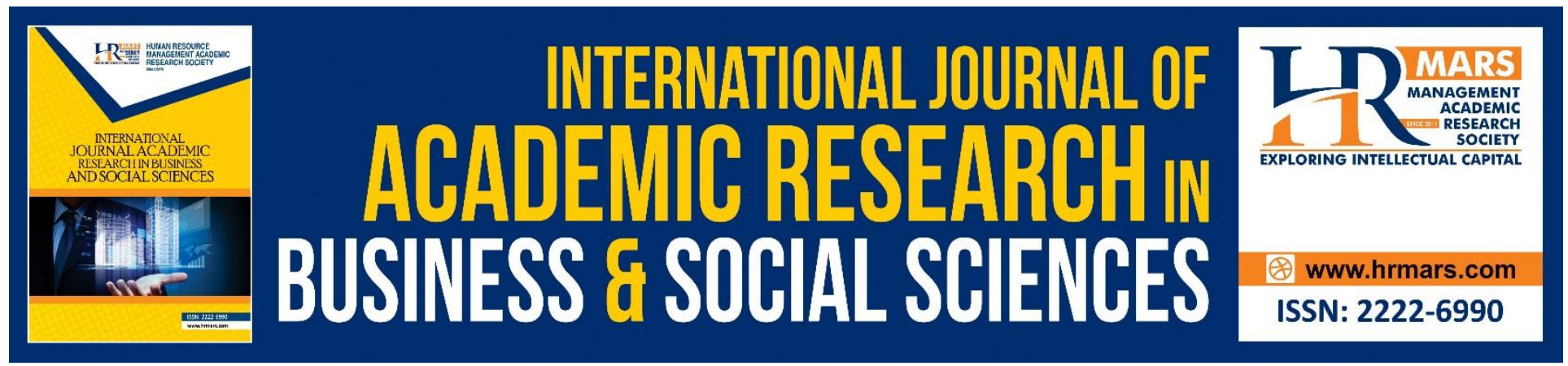

\title{
Mainstream Teachers' Competency Requirement for Inclusive Education Program
}

\author{
Norfishah Mat Rabi \& Mohd Yusof Zulkefli
}

To Link this Article: http://dx.doi.org/10.6007/IJARBSS/v8-i11/5354

DOI: $10.6007 /$ IJARBSS/v8-i11/5354

Received: 24 Oct 2018, Revised: 30 Nov 2018, Accepted: 02 Nov 2018

Published Online: 04 Dec 2018

In-Text Citation: (Rabi \& Zulkefli, 2018)

To Cite this Article: Rabi, N. M., \& Zulkefli, M. Y. (2018). Mainstream Teachers' Competency Requirement for Inclusive Education Program. International Journal of Academic Research in Business and Social Sciences, 8(11), 1779-1791.

Copyright: (C) 2018 The Author(s)

Published by Human Resource Management Academic Research Society (www.hrmars.com)

This article is published under the Creative Commons Attribution (CC BY 4.0) license. Anyone may reproduce, distribute, translate and create derivative works of this article (for both commercial and non-commercial purposes), subject to full attribution to the original publication and authors. The full terms of this license may be seen at: http://creativecommons.org/licences/by/4.0/legalcode

Vol. 8, No. 11, 2018, Pg. 1779 - 1791

Full Terms \& Conditions of access and use can be found at http://hrmars.com/index.php/pages/detail/publication-ethics 


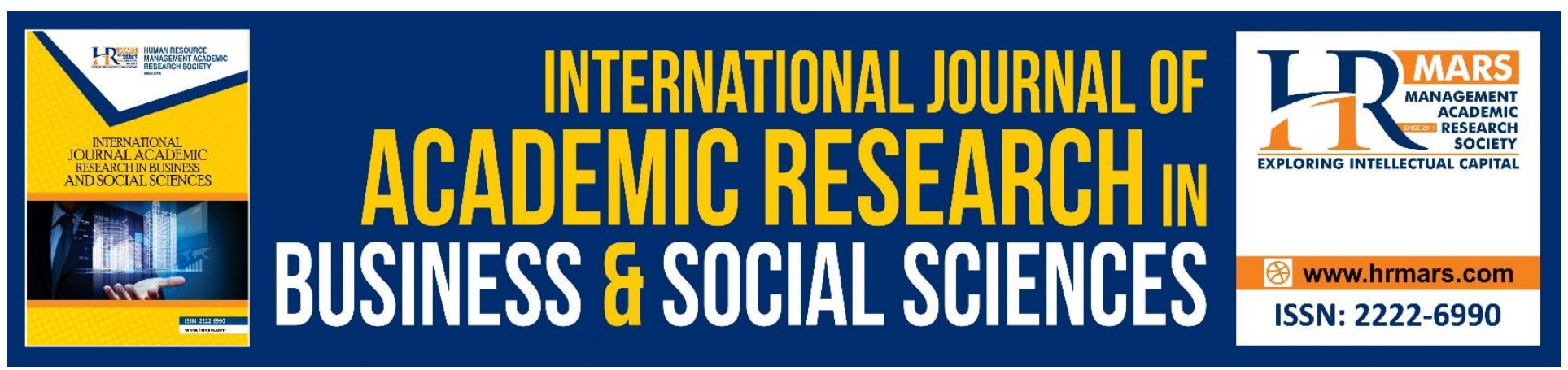

\title{
Mainstream Teachers' Competency Requirement for Inclusive Education Program
}

\author{
Norfishah Mat Rabi ${ }^{1}$ \& Mohd Yusof Zulkefli ${ }^{2}$ \\ ${ }^{1}$ Faculty of Human Development, Universiti Pendidikan Sultan Idris, Malaysia \\ ${ }^{2}$ Faculty of Arts and Social Sciences, Universiti Tunku Abdul Rahman, Malaysia
}

\begin{abstract}
The purpose of this study is to examines specifically on the competencies of mainstream teacher in inclusive program. The three objectives were to identify the competencies in evaluation and monitoring, teaching strategies and classroom management. This case study was conducted at three school involving 15 mainstream teachers. The data collection period was four months. Data collection methods used were observation, interviews and document analysis. The observation was conducted five times in the classroom. Two sets of interview questions were set up and used in four interview sessions. The finding showed that all participant agreed with the 25 characteristic of competencies need to be acquired by mainstream teacher in inclusive education. However, results indicated that participants were not fully competent in teaching inclusive classroom in the context of evaluation and monitoring, teaching strategies and classroom management. For competencies in evaluation and monitoring, only $40 \%$ of mainstream teacher had achieved, in teaching strategies $36.77 \%$ and in classroom management $23.23 \%$. It is suggested that mainstream teachers should have go for inservice training to ensure they have better competencies in teaching the inclusive education program in the future. Competencies in teaching inclusive education is important in order to achieve successful inclusion for student with learning disabilities in school.
\end{abstract}

Keywords: Competencies, Inclusive Education, Mainstream Teacher

\section{Introduction}

It can be very difficult for mainstream teacher to teach student with disabilities within inclusion classrooms because both disabled and non-disabled students learn together in same classrooms. Skills and competencies are required by mainstream teachers in order to serve students with disabilities in inclusive setting. Competency were include professional knowledge, teaching techniques, classroom management, collaboration, assessment and evaluation, adaptive instruction, and support system. An ability to plan, control and facilitate interaction in the classroom need to be fulfilled by mainstream teacher for the successful inclusion in school. It is important to provide teachers with the knowledge, skills and understanding of inclusive so they can play an effective role in school_(Sharma, Simi \& Forlin, 2015). With more preparation and competent teachers, the inclusive 
education program will have a positive impact on the community awareness of the education for student with disabilities. Successful inclusive education program is depends on teachers' competency to work with student with disabilities in the classroom. In terms of inclusive education in school, the teacher should have new paradigm in teaching skills, an ability to recognize the personal and social significance of student with disabilities and to take responsibility for the quality of the teaching process. Mainstream teacher should have competence in teaching approach, methods and teaching technique to develop readiness' to work with student with disabilities in inclusive setting. Teachers can better help student with disabilities learning process by altering their teaching styles. But however, in many teacher preparation programs, students are not receiving training on classroom management and there is little evidence to show that classroom behavior management (Allday, Neilsen-Gatti, \& Hudson, 2013).

For the successful implementation of inclusive program in school, mainstream teachers required more skills and competencies in understanding student with disabilities especially the attitude and behavior that positively influence students' learning. To develop the competency, mainstream teachers must have variety of skills such as preparing and organizing materials to conducting daily lessons, practicing procedure to handling students behavior and designing a learning environment that encourages active participation by students in group or individual learning activities. To ensure the readiness of mainstream teachers for the inclusion, they should be given an opportunities to get along with special needs students (Chambers \& Lavery, 2012; Forlin \& Chambers, 2011), learning about inclusive education policies and policies (Armstrong et al., 2010) and received support for inclusive education at school (Loreman et al., 2013). On the other hand, teachers need to think what are the important skills and competencies for them to be prepared in order to achieve learning process in the inclusive classroom.

\section{Literature Review}

The most important competency that should be acquired by mainstream teachers were skills in managing the teaching and learning environment, understanding student behavior and developing social interaction skills. Mainstream teachers should be prepared with practical knowledge or application of the skills in working with students with disabilities than theoretical knowledge. Many factors will influence mainstream teacher readiness in teaching students with disabilities in the inclusive setting such as qualification, training in special education, teaching experience and perceptions of importance of inclusion. Killoran et al., (2014) show that inclusive education courses have successfully changed the perception of regular teachers on inclusive programs and provide a solid foundation of knowledge to be practiced in future teaching. A key factor in the success of inclusive education is the teachers' competence to work with student with disabilities practically and theoretically. Inclusive strategies are insufficient to enhance positive attitudes, effectiveness of teaching, or reduce anxiety without associating it with a broader context of inclusive education (Sharma, Simi \& Forlin, 2015). In terms of inclusive education, the mainstream teacher should have a strong conceptual thinking, the ability to recognize the significance learning activities for student with disabilities and to take responsibility for the quality of the learning process.

The common practice in inclusive program is educating student with disabilities together with the typical student who have no such disabilities. Inclusive according to Lewis and Doorlag (2011) is 
a place where students with special needs learning alongside mainstream students in the same setting. So inclusive education goes beyond physical presence of a child in the classroom situation; going through the same curriculum as the non-disabled, appearing at the same examination with them and acquiring the same certificate (Kusuma et al, 2013). Spreading the ideas of inclusive education has actualized the need to study such as the willingness and the competency of the teacher to work in inclusive education. It is important to provide teachers with the knowledge, skills and understanding of inclusive (Sharma, Simi \& Forlin, 2015), so they can be more competent in school. Nevertheless, preparation of the mainstream teacher for inclusive education is extremely challenging for the teachers' training institute. Institution must provide a relevant curriculum for the inclusion such as content-pedagogical curriculum, moral training-based, or in the independently and creatively training, which are appropriate for use with specific educational needs, whether for children with physical and intellectual disabilities, or children with multiple disabilities. The willingness of teachers to implement inclusive education is considered in skills and competencies as a key success factor in the inclusive process. As mentioned by Boyle et. al, (2013) inclusive education policies should be consistent with the practice of teachers to be competently teach. The competencies of teachers to work in inclusive education is determined by the teacher's role in the inclusion of student with disabilities in the inclusive education environment. However, Bukvić (2014) proven that some teachers that have positive attitudes about inclusive education would not accept student with special needs if could make choice. This happened because teacher have very little or limited knowledge about teaching student with special needs, and their attitudes are mostly negative for supporting inclusive education. As Walton et al. (2014) concluded that equipping teachers to be effective in inclusive settings requires more than workshops alone. Furthermore, competencies of examined teacher in regular school are not equally done.

Inclusion involves all kinds of practices that are unlimitedly practices of good teaching. What good teachers do is to think thoughtfully about children and develop ways to reach all children. It would be difficult to address all of the specific knowledge and skills teachers must demonstrate to include students with disabilities successfully, however it is possible to identify general areas of knowledge and skills (Allday, Neilsen-Gatti, \& Hudson, 2013). Planning for differentiation involves thinking about different ways of learning project and may be changed to meet student's needs. Teacher can consider aspects like students current abilities, their interest and ways they learn best. Goss et al. (2015) suggest that school leaders should provide teachers with the time, tools and the professional learning needed to track progress of students and embed targeted teaching into their practice. The teacher is sufficiently responsible for educational planning, instructional, evaluation, assessment, and curriculum adaptation and so on. Any teacher dealing with diverse abilities in regular classrooms will feel that including these children can be a difficult and complex matter. The complexity involved in instructing a range of learners with a variety of experiences, backgrounds, skills and abilities poses challenges for teachers. The necessity of catering for individual differences in inclusive classrooms has resulted in the development of pedagogical practices that aim to ensure that all students, including those with disabilities or difficulties, benefit from the learning environment (van Kraayenoord, Waterworth \& Brady, 2014).

Generally, some mainstream teachers think inclusion demands high levels of teaching competence and requested organizational make changes on aim for promoting affective learning for 
student with disabilities. In order to achieve this, mainstream teachers need to have knowledge of the different types of special education needs children and the practical teaching strategies needed to teach them effectively in mainstream classrooms (Hornby, 2015). Developing the knowledge and skills of teacher, school staff, and giving schools clearer guidance and support to better respond to the needs of students with disabilities should take into consideration by government. Providing future inclusive education students with sound knowledge and practice related to understanding disability within the context of school, differentiating instruction for various abilities, successfully managing students' behavior, and working together with colleagues to meets student needs can only assist in making teachers stronger candidates when they enter the field, and more likely to work together effectively in meeting the needs of diverse learners (Allday, Neilsen-Gatti, \& Hudson, 2013). As Urton, Wilbert and Hennemann (2014) concluded that, in the overall process of school inclusion, principals, in collaborating with their teaching staff, play a key role in building a school culture promoting inclusion. Ball and Green (2014) added that school leaders act as the lead innovators for practices that address the learning needs of all students and align teachers' efforts to this goal.

\section{Methodology}

The design of this study is based on a case study. This study examines specifically on the competencies of mainstream teacher in teaching inclusive program. This study uses purposive sampling. The sample of the study is 15 mainstream teachers at three schools in district of Perak. For data collection, this case study used interviews, observations and document analysis. An interview session was conducted to obtain qualitative data. Interviews were conducted individually and focus groups with mainstream teachers participant for five times. Observation is carried out during teaching and learning activities and was conducted for five times. Instruments used in collecting data were checklists, field notes, and video recordings. Four checklists used as a data collection tool were (i) competencies in teaching strategies, (ii) competencies in classroom management, and (iii) competencies in evaluation and monitoring. Documents referenced are (i) Daily Lesson Plan, (ii) Annual Teaching Pelan, and (ii) the assignments. This case study was analyzed and reported descriptively and supported by reference statistics. The findings is reported base on the four main objective: (i) competencies of mainstreams teachers for inclusion, (ii) competencies in teaching strategies, (iii) competencies in class management, and (iv) evaluation and monitoring. Data were analyzed descriptively and make used of observation, interview and document analysis method.

\section{Results}

The mainstream teachers should inculcate the skills and competencies in them to prepare them for inclusive education. To identify the competencies of mainstream teacher, interview, observation, and field notes were conducted for data collection. Table 1 shows the findings of competencies of mainstream teachers. 
INTERNATIONAL JOURNAL OF ACADEMIC RESEARCH IN BUSINESS AND SOCIAL SCIENCES Vol. 8, No. 11, Nov, 2018, E-ISSN: 2222-6990 @ 2018 HRMARS

Table 1. Competencies for inclusion

\begin{tabular}{|c|c|c|}
\hline & & Skills in evaluation and monitoring \\
\hline 1 & ASP & Ability to solve problem \\
\hline 2 & AAS & Ability to assess student learning skills \\
\hline 3 & ASA & Ability to value all kinds of prior skills of students \\
\hline 4 & ADA & Ability to developing alternative assessments \\
\hline 5 & AAN & Ability to assess individual needs of student \\
\hline 6 & ASG & Ability to set appropriate, realistic and measurable goals for the student \\
\hline 7 & AEF & Ability to evaluate each student's level of functioning \\
\hline 8 & AEP & Ability to evaluate student progress. \\
\hline 9 & AKR & Ability to know the rights of special needs children \\
\hline 10 & ADR & $\begin{array}{l}\text { Ability to determine the role of parents and community and NGOs in } \\
\text { education of student with disabilities. }\end{array}$ \\
\hline No & Code & Skills in teaching strategies \\
\hline 1 & MA & Ability to modify assignments for students \\
\hline 2 & DCA & Ability to design learning activities for all students \\
\hline 3 & UVI & Ability to use a variety of instructional strategies effectively \\
\hline 4 & AML & Ability to adapt materials in lessons \\
\hline 5 & PBT & Ability to provide the best teaching approach. \\
\hline 6 & HUDM & $\begin{array}{l}\text { Ability to help others in using different methods of adopting teaching } \\
\text { methods for successful inclusion }\end{array}$ \\
\hline 7 & ACC & $\begin{array}{l}\text { Ability to adapt curriculum content to be suited with the needs of student } \\
\text { in the class }\end{array}$ \\
\hline 8 & ARM & $\begin{array}{l}\text { Ability to procure relevant special educational material from special } \\
\text { teacher/educator/support group }\end{array}$ \\
\hline \multirow[t]{2}{*}{9} & DVTS & $\begin{array}{l}\text { Ability to design variety of alternative teaching strategies to compensate } \\
\text { the deficient area of the student with disabilities }\end{array}$ \\
\hline & & Skills in class management \\
\hline 1 & APPE & Ability to plan appropriate classroom physical environment \\
\hline 2 & ALE & Ability to accommodating and adjusting learning environment \\
\hline 3 & ACS & Ability to counsel special needs students in the classroom \\
\hline 4 & ACC & Ability to provide the conducive classroom environment \\
\hline 5 & ARSP & Ability to rearrange classroom sitting position \\
\hline 6 & SCE & Ability to set up comfortable environment \\
\hline
\end{tabular}

Table 1 showed the finding from the interview with mainstream teachers about skills which were contributed for the competencies in teaching inclusive program. The most important skills need to be acquired by mainstream teachers were the evaluation and monitoring skills. In this competencies, the participants said the mainstream teachers should have an ability to (i) solve problem, (ii) assess 
the skills a student, (iii) value all kinds of prior skills of students, (iv) developing alternative assessments, (v) assess individual needs of student, (vi) set appropriate, realistic and measurable goals for the student, (vii) evaluate each student's level of functioning, (viii) evaluate student progress, (ix) know the rights of special needs children, and (x) determine the role of parents and community and NGOs in education of student with disabilities.

Competencies in teaching strategies were identified as the second important skills to be fulfilled by mainstream teachers in inclusive classroom. The skills required were the ability to (i) modify assignments for students, (ii) design learning activities for all students, (iii) use a variety of instructional strategies effectively, (iv) adapt materials in lessons, (v) provide the best teaching approach, (vi) help others in using different methods of adopting teaching methods for successful inclusion, (vii) adapt curriculum content to be suited with the needs of student in the class, (viii) to procure relevant special educational material from special teacher or support group, and (ix) design variety of alternative teaching strategies to compensate the deficient area of the student with disabilities. The third category of the competencies were the skills in classroom management. To be successful in teaching inclusive education, mainstream teachers must have an ability (i) to plan appropriate classroom physical environment, (ii) accommodating and adjusting learning environment, (iii) counsel special needs students in the classroom, (iv) provide the conducive classroom environment, ( $v$ ) rearrange classroom sitting position, and (vi) set up comfortable environment.

\section{Evaluation and Monitoring}

Skill in evaluation and monitoring student in the classroom was prove to be the most important competencies in inclusive education. The finding is showed in Table 2.

Table 2. Competencies in evaluation and monitoring

\begin{tabular}{|c|c|l|c|c|}
\hline No & Code & \multicolumn{1}{|c}{ Skills in evaluation and monitoring } & \multicolumn{2}{c|}{ No of Participant } \\
\cline { 3 - 5 } & & & Yes & No \\
\hline 1 & ASP & Ability to solve problem & 8 & 7 \\
\hline 2 & AAS & Ability to assess student learning skills & 10 & 5 \\
\hline 3 & ASA & Ability to value all kinds of prior skills of students & 6 & 9 \\
\hline 4 & ADA & Ability to developing alternative assessments & 7 & 8 \\
\hline 5 & AAN & Ability to assess individual needs of student & 5 & 10 \\
\hline 6 & ASG & $\begin{array}{l}\text { Ability to set appropriate, realistic and measurable } \\
\text { goals for the student }\end{array}$ & 6 & 9 \\
\hline 7 & AEF & Ability to evaluate each student's level of functioning & 5 & 10 \\
\hline 8 & AEP & Ability to evaluate student progress & 7 & 8 \\
\hline 9 & AKR & Ability to know the rights of special needs children & 5 & 10 \\
\hline 10 & ADR & $\begin{array}{l}\text { Ability to determine the role of parents and } \\
\text { community and NGOs in education of student with } \\
\text { disabilities. }\end{array}$ & 3 & 12 \\
\hline & & Total & 62 & 88 \\
\hline
\end{tabular}


Table 2 showed the list of skills in evaluation and monitoring for mainstream teachers to be a competent teacher in the inclusive education program. Findings clearly showed the skills were (in rank order) ASS, ASP, ADA, AEP, ASA, ASG, AAN, AEF, AKR, and ADR. In details, 10 participants have had the ability to assess student learning skills (AAS). It is a compulsory for teachers to have an ability in ASS (assess student learning skills) as a preparation to plan a strategy for teaching and learning process effectively. However, only three participants have the ability to determine the role of parents and community and NGOs in education of student with disabilities (ADR) was not encourage to be acquired by mainstream teachers in the inclusive program. Overall, $41.33 \%$ participants have had a skill in evaluation and monitoring and in order to be a competent inclusive teacher. Nevertheless $58.67 \%$ were not. From the interview session, the participants explained that to have the skill they must attend a special course or workshop, focusing on special education but most of the participants said they were not offered to attend any courses.

\section{Teaching Strategies}

Mainstream teachers need to be competent in teaching strategies for the successful inclusion. To teach a variety of student in a classroom is quite challenging for mainstream teachers. What are the skills need to be mastered by mainstream teacher in the inclusive classroom? To answer this question, a checklist of observation was used to identify the skill of teachers in order to be competent in teaching student with learning disabilities in the inclusive education. Table 3 shows the result of the observation done.

Table 3. Competencies in teaching strategies

\begin{tabular}{|c|c|c|c|c|}
\hline \multirow[t]{2}{*}{ No } & \multirow[t]{2}{*}{ Code } & \multirow[t]{2}{*}{ Skills in teaching strategies } & \multicolumn{2}{|c|}{ No of Participant } \\
\hline & & & Yes & No \\
\hline 1 & AMA & Ability to modify assignments for students & 10 & 5 \\
\hline 2 & ADCA & Ability to design classroom activities for all students & 7 & 8 \\
\hline 3 & AVIS & $\begin{array}{l}\text { Ability to use a variety of instructional strategies } \\
\text { effectively }\end{array}$ & 7 & 8 \\
\hline 4 & AAM & Ability to adapt materials in lessons & 6 & 9 \\
\hline 5 & APBT & Ability to provide the best teaching approach & 4 & 11 \\
\hline 6 & AUDM & $\begin{array}{l}\text { Ability to help others in using different methods of } \\
\text { adopting teaching methods for successful inclusion }\end{array}$ & 5 & 10 \\
\hline 7 & AACC & $\begin{array}{l}\text { Ability to adapt curriculum content to be suited with } \\
\text { the needs of student in the class }\end{array}$ & 6 & 9 \\
\hline 8 & ARM & $\begin{array}{l}\text { Ability to procure relevant special educational material } \\
\text { from special teacher/educator/support group }\end{array}$ & 8 & 7 \\
\hline 9 & ADAT & $\begin{array}{l}\text { Ability to design variety of alternative teaching } \\
\text { strategies to compensate the deficient area of the } \\
\text { student with disabilities }\end{array}$ & 4 & 11 \\
\hline & & Total & 57 & 78 \\
\hline
\end{tabular}


Table 3 showed the findings of observation on competencies in teaching strategies. Skill in teaching strategies were (in rank order) AMA, ARM, ADCA, AVIS, AAM, AACC, AUDM, APBT, and ADAT. Observation findings showed that $42.22 \%$ of participants have had a competencies in teaching strategies, whereas $57.78 \%$ were not. 10 participants were identified have had an ability to modify assignments for students. In the inclusive program, assignments were prepared for the student according to the normal syllabus but teacher must modify the assignments to be suited with the student needs especially for the student with disabilities. From the interview finding, the participant explained that without modifying the assignment, student were unable to complete the assignment given to them. Example of modifying the assignment were number of question, total marks, level of question, or minimize the item. Out of nine skills, the ability to provide the best teaching approach (APBT) and an ability to design variety of alternative teaching strategies to compensate the deficient area of the student with disabilities (ADAT) were prove to be the lowest skill acquired by the participants. From the interview finding, participant had mentioned that they were not competent in both skills because teaching approaches and teaching strategies required specific training in special education courses, formally or informally.

\section{Classroom Management}

Classroom management is one of the skill that should be acquired by mainstream teachers in terms of achieving competencies in inclusive education. The finding is showed in Table 4.

Table 4. Competencies in classroom management

\begin{tabular}{|c|c|l|c|c|}
\hline & & \multicolumn{1}{|c|}{ Skills in class management } & \multicolumn{2}{|c|}{ No of Participant } \\
\cline { 3 - 4 } & APPE & $\begin{array}{l}\text { Ability to plan appropriate classroom physical } \\
\text { environment }\end{array}$ & 7 & 8 \\
\hline 2 & ALE & $\begin{array}{l}\text { Ability to accommodating and adjusting learning } \\
\text { environment, co-ordination with colleagues and co- } \\
\text { operative relationship with parents }\end{array}$ & 5 & 10 \\
\hline 3 & ACS & $\begin{array}{l}\text { Ability to counsel special needs students in the } \\
\text { classroom }\end{array}$ & 5 & 10 \\
\hline 4 & ACC & $\begin{array}{l}\text { Ability to provide the conducive classroom } \\
\text { environment }\end{array}$ & 7 & 8 \\
\hline 5 & ARSP & Ability to rearrange classroom sitting position & 6 & 9 \\
\hline 6 & SCE & Ability to set up comfortable environment & 36 & 54 \\
\hline & & Total & & 9 \\
\hline
\end{tabular}

Table 4 showed that $40 \%$ of participants have skills in classroom management in inclusive program. The skill were APPE, ALE, ACS, ACC, ARSP, and SCE. Findings from the observation showed that the highest skill were the ability to plan appropriate classroom physical environment (APPE) and an ability to rearrange classroom sitting position (ARSP). From the focus group interview session, the participant said that classroom environment should be given attention if the teacher want to be competent in inclusive education. Teacher must have skill in providing the conducive classroom 
INTERNATIONAL JOURNAL OF ACADEMIC RESEARCH IN BUSINESS AND SOCIAL SCIENCES

Vol. 8, No. 11, Nov, 2018, E-ISSN: $2222-6990$ @ 2018 HRMARS

environment. To that they must be able to rearrange classroom sitting position (ARSP) and set up comfortable environment (SCE). The lowest skill was an ability to counsel special needs students in the classroom (ACS). According to the interview findings, this ability is difficult to acquire because most of the participant were not from the special education field.

\section{Discussion}

Teacher's competency includes all the skills required in a teacher for conveying units of knowledge, application and attitude to student in inclusive program. Regarding for successful mainstreaming of the inclusive education, it is imperative to improve the quality of teachers in relation to competencies required in teaching strategies, classroom management, and in evaluation and monitoring. Competencies of skill in evaluation and monitoring is crucial for preparing mainstream teacher to be competent in teaching inclusive education. Its mean mainstream teachers must have ability to developing alternative assessments, evaluate student progress, evaluate each student's level of functioning, assess individual needs of student, solve problem, value all kinds of prior skills of students, and determine the role of parents and community and NGOs. Mainstream teachers are required to exhibit competency in assessment in order to identify the specific needs of students. Assessment is one of the most vital skills for a regular classroom teacher to have in the implementation of inclusive education programs (McLoughlin \& Lewis, 2008). The teacher has to employ both, basic skills such as gathering, learning and background information of differently abled students and also highly specialized skills such as selecting, administering, scoring and interpreting standardized measurement instruments. Teachers need to know how to developing a record of assessment and using cognitive strategies to improve learning (Florian, 2012; Lancaster \& Bain, 2010; Philpot, Furey \& Penney, 2010). In addition, mainstream school teachers must develop the skills necessary to work effectively with parents and with other professionals, such as psychologists, therapists, social workers and specialist teachers, in order to implement effective inclusive special education (Hornby, 2015).

Competencies in teaching strategies was also important for successful inclusive education practice. The required skills in teaching strategies were the ability to modify assignments for students, design classroom activities for all students, use a variety of instructional strategies effectively, adapt materials in lessons, adapt curriculum content to be suited with the needs of student in the class, and provide the best teaching approach. It is clearly proven that teachers need to know how to improve teaching and learning, or innovate in teaching and should be exposed to various teaching strategies (Florian, 2012; Lancaster \& Bain, 2010; Philpot, Furey \& Penney, 2010). Adaptation in teaching strategies such as cooperative learning and peer-tutoring, can facilitate student learning process (Garrote, Sermier, \& Moser, 2017). Ability to provide the best teaching methods equally with inclusive values support the way teachers deal with complex features in the context of the 21st century education (Di Gennaro et al., 2014). When selecting academic tasks for students to do independently at their seats, the teacher must be confident that each student has the ability to do the task that is assigned to him or her without needing continuous teacher attention and support (Polirstok, 2015). Adaptation curriculum and content to be suited with student with disabilities is very important. As argued by Farrell (2010), the priority for student with disabilities must be that they have access to curricula which are appropriate for them, not that they are fitted into a national curriculum 
which was designed for the mainstream population. An important issue in inclusive special education is to achieve the right balance for each child with special needs between an academic or developmental curriculum, which is focused on the needs of the majority of children, and a functional curriculum which addresses the specific educational needs of children with special needs (Hornby, 2015).

Classroom management is one of the skills that need to be competent by mainstream teacher in inclusive education program. Competencies in classroom management is generally based on the ability to plan appropriate classroom physical environment, rearrange classroom sitting position, providing the conducive classroom environment, and set up comfortable environment for the student. Effective classroom management strategies is an important competencies to support teaching and learning process in the classroom. It is clearly proven that classroom management skill play an important key role for mainstream teacher to succeed in inclusive education program. Creating a learning environment for inclusive classrooms that is well managed with clear structures and routines is of the utmost importance for student success (Wong \& Wong, 2014). Creating a climate conducive to students complying with behavioral expectations, volunteering answers or taking on more challenging assignments is closely tied to the emotional temperature of the classroom (Polirstok, 2015). Creating an emotionally safe classroom environment where students can be successful involves high approval interactions between students and teachers.

\section{Conclusion}

Inclusion of students with disabilities in general education classes still in progress. This study was conducted to examine the competencies of mainstream teacher related to skill in evaluation and monitoring, teaching strategies, and classroom management. To make inclusion as a placement for students with various disabilities carried out successfully, teacher will have to change the paradigm on inclusive education in order to meet the needs of the student. The teachers must be well equipped with the knowledge of various disabilities, assessment of student, managing classroom in and propose an effective approach in teaching strategies. They need program for skills development to manage classroom and meet the needs of special children. Successful inclusive education require mainstream teacher working together with colleagues to meets student needs formally and informally.

\section{Acknowledgement}

The authors would like to express utmost appreciations to the Research Management and Innovation Center (RMIC) for the allocation of the Research Grant University.

\section{Corresponding Author}

Norfishah Mat Rabi,

Faculty of Human Development, Universiti Pendidikan Sultan Idris, Malaysia

Email: norfishah@fpm.upsi.edu.my 
INTERNATIONAL JOURNAL OF ACADEMIC RESEARCH IN BUSINESS AND SOCIAL SCIENCES

Vol. 8, No. 11, Nov, 2018, E-ISSN: 2222-6990 @ 2018 HRMARS

\section{References}

Allday, R.A., Neilsen-Gatti, S. \& Hudson, T.M. (2013). Preparation for Inclusion in Teacher Education Pre-Service Curricula. Teacher Education and Special Education, 36(4) 298-311.

Armstrong, A.C., Armstrong, D. \& Spandagou, I. (2010). Inclusive education: International policy and practice. London: Sage Publications.

Ball, K. \& Green, R. L. (2014). An Investigation of the attitudes of school leaders toward the inclusion of students with disabilities in the general education. National Forum of Applied Educational Research Journal, 27(1\&2), 57-76.

Boyle, C.,Topping, K., \& Jindal-Snape, d. (2013). Teachers' attitudes towards inclusion in high schools. Teachers and Teaching Theory and practice. 19(5), 527-542.

Bukvić, Z. (2014). Teachers' competency for inclusive education. European Journal of Social and Behavioural Sciences, 23(1), 1586-1590.

Chambers, D. J., \& Lavery, S. D. (2012). Service-learning: A valuable component of pre service teacher education. Australian Journal of Teacher Education, 37(4).

Di Gennaro, D. C., Pace, E. M. \& Iolanda, Z. \& Aiello, Z. (2014). Teacher capacity building through critical reflective practice for the promotion of inclusive education. Problems of Education in the 21st Century, 60, 54-65.

Farrell, M. (2010). Debating Special Education. London: Routledge

Florian, L. \& Linklater, H. (2010). Preparing teachers for inclusive education: using inclusive pedagogy to enhance teaching and learning for all. Cambridge Journal of Education. 40 (4), 369-386.

Florian, L. (2012). Teacher education for inclusion. In C. Forlin (Ed.), Future Directions for Inclusive Teacher Education. Oxon, UK.: Routledge.

Garrote, A., Sermier Dessemontet, R., Moser Opitz, E. (2017). Facilitating the social participation of pupils with special educational needs in mainstream schools: A review of school-based interventions. Educational Research Review, 20(1), 12-23.

Goss, P., Hunter, J., Romanes, D. \& Parsonage, H. (2015). Targeted teaching: How better use of data can improve student learning. Gattan Institute, Victoria.

Hornby, G. (2015). Inclusive special education: development of a new theory for the education of children with special educational needs and disabilities. British Journal of Special Education, 42(3),251-256.

Killoran, I., Woronko, D. \& Zaretsky, H. (2014). Exploring pre service teachers' attitudes towards inclusion. International Journal of Inclusive Education, 18(4), 427-442.

Lancaster, J. \& Bain, A. (2010). The design of pre-service inclusive education courses and their effects on self-efficacy: A comparative study. Asia-Pacific Journal of Teacher Education, 38(2), 117-128.

Lewis, R.B. \& Doorlag, D. H. (2011). Teaching students with special needs in general education classrooms. 8th Ed. New Jersey: Pearson Education, Inc.

Loreman, T., Sharma, U., \& Forlin, C. (2013). Do pre-service teachers feel ready to teach in inclusive classrooms? A four-country study of teaching self-efficacy. Australian Journal of Teacher Education, 38 (1), Article 3. Available at: http://ro.ecu.edu.au/ajte/vol38/iss1/3 http://dx.doi.org/10.14221/ajte.2013v38n1.10

McLoughlin, J.A. \& Lewis, R. B. (2008). Assessing Students with Special Needs (7th Edition). Pearson. 
Nichols, S. C. \& Sheffield, A. N. (2014). Is there an elephant in the room? Considerations that administrators tend to forget when facilitating inclusive practices among general and special education teachers. National Forum of Applied Educational Research Journal, 27(1\&2), 31-44.

Philpot, D. F., Furey, E. \& Penney, S.C. (2010). Promoting leadership in the ongoing profesional development of teachers: Responding to globalization and inclusion. Exceptionality Education International 20(2), 38-54

Polirstok, S. (2015). Classroom Management Strategies for Inclusive Classrooms. Creative Education, 6, 927-933.

Sharma, U. (2011). Changing heart, head, and hands of teachers to teach in inclusive classrooms: Why and how? Bangladesh Education Journal, 10(2), 7-18.

Sharma, U., Forlin, C., Deppeler, J., \& Guang-xue, Y. (2012). Reforming teacher education for inclusion in developing countries in the Asia Pacific Region, Asian Journal of Inclusive Education, 3-16.

Sharma, U., Simi, J., \& Forlin, C. (2015). Preparedness of Pre-service Teachers for Inclusive Education in the Solomon Islands. Australian Journal of Teacher Education, 40(5).

Urton, K., Wilbert, J. \& Hennemann, T. (2014). Attitudes towards inclusion and self-efficacy of principals and teachers. Learning Disabilities: A Contemporary Journal, 12(2), 151-168.

van Kraayenoord, C., Waterworth, D. \& Brady, T. (2014). Responding to individual differences in inclusive classrooms in Australia. Journal of International Special Needs Education, 17(2), 4859.

Walton, E., Nel, N.H., Muller, H. \& Lebeloane, O. (2014). You can train us until we are blue in our faces, we are still going to struggle: Teacher professional learning in a full-service school. Education as Change, 18(2), 319-333.

Wong, H., \& Wong, R. (2014). The Classroom Management Book. Mountainside, CA: Wong Publishing. 